\title{
Heavy Metals, Metalloids, Their Toxic Effect and Living Systems
}

\author{
Ferdous Seraj1,2*, Tania Rahman ${ }^{3}$ \\ ${ }^{1}$ Department of Environmental Science and Management, North South University, Dhaka, Bangladesh \\ ${ }^{2}$ School of Civil, Environmental and Chemical Engineering, RMIT University, Melbourne, Australia \\ ${ }^{3}$ Department of Biochemistry and Molecular Biology, University of Dhaka, Dhaka, Bangladesh \\ Email: *rtania7@gmail.com
}

How to cite this paper: Seraj, F. and Rahman, T. (2018) Heavy Metals, Metalloids, Their Toxic Effect and Living Systems. American Journal of Plant Sciences, 9, 2626-2643.

https://doi.org/10.4236/ajps.2018.913191

Received: October 1, 2018

Accepted: December 5, 2018

Published: December 17, 2018

Copyright (c) 2018 by authors and Scientific Research Publishing Inc. This work is licensed under the Creative Commons Attribution International License (CC BY 4.0).

http://creativecommons.org/licenses/by/4.0/

\section{(c) (i) Open Access}

\begin{abstract}
Pollution of the biosphere by heavy metals is a global hazard that has accelerated since the beginning of the industrial revolution. Toxic heavy metals are harmful to living organisms even at low concentrations whereas heavy metals that are essential trace elements are required by plants at low concentrations but can become toxic at high concentrations. Heavy metals released from different sources accumulate in soil and, where bioavailability is high enough; can adversely affect soil biological functioning and other properties, leading to the loss of soil and ecosystem fertility and health. It is important that heavy metal contaminated sites are remediated as heavy metals do not decompose into less harmful substances like organic contaminants, and thus are retained in the soil. In this review, we survey and analysis our current knowledge and understanding of the abundance of heavy metals in soil, their phytoavailability, their toxicity, their uptake and transport, role of rhizobia and other microbes and overall rhizosphere processes.
\end{abstract}

\section{Keywords}

Heavy Metal, Arsenic, Zinc, Nickel, Contaminated Land,

Metal Bioavailability, Metal Toxicity, Rhizobia, Rhizosphere

\section{Introduction}

Soil is an important resource that produces food and other raw materials for humans. However, soil is often a sink for wastes, including heavy metals [1], from a variety of human activities. In a risk based approach, soil can be classified as contaminated if the bioavailable concentrations of heavy metals is high enough to cause harm directly or indirectly to humans, animals, plants, water 
quality, the wider ecosystem, buildings and or construction materials [2] [3].

Some heavy metals are essential for living organisms at lower concentrations e.g. $\mathrm{Co}, \mathrm{Cu}, \mathrm{Cr}, \mathrm{Mn}$ and $\mathrm{Zn}$ and are known as trace elements or micronutrients [1] [4]. The term toxic heavy metalloids include those elements that are nonessential and include heavy metals such as $\mathrm{Cd}, \mathrm{Pb}, \mathrm{Ba}, \mathrm{Hg}, \mathrm{Sb}, \mathrm{Tl}, \mathrm{As}$ and $\mathrm{U}$ [1] [2] [5].

Heavy metals are emitted into the soil environment through anthropogenic and geogenic processes [6]. In nature, heavy metals commonly occur in soil parent materials [1] [7] and the main natural source of metals and metalloids in the soil environment is the weathering of parent material [1] [8].

\section{Heavy Metals and Metalloids in Soils}

\subsection{Arsenic}

Arsenic has a crustal average of 1.5 - 2 ppm [9]. The background concentration range of As in soil is $1-40 \mathrm{mg} / \mathrm{kg}$ [10] with an average As concentrations in soils of approximately $5 \mathrm{ppm}$. In natural soils, high As concentrations are often related to sulfide deposits and their weathering to produce local mineralised soils [9]. Anthropogenic sources of As contamination in soil include sulfide mining, fossil fuels combustion, smelting, use of As containing pesticides and copper chrome arsenate used as a wood preservative [9] [11]. In addition, groundwater has been found to be contaminated with As in more than 20 countries including the United States of America, China, India and Bangladesh [11] and using this water to irrigate soils can create As contamination issues such as leaving risks of soil accumulation of the toxic element and possible exposure of As contamination to the food chain through plant uptake and animal consumption [12]. In Australia, a large source of Ascontamination comes from arsenic-based cattle dips. Arsenical dip solutions were used in the past for cattle tick and sheep lice control [13].

\subsection{Zinc}

Zinc has a crustal average of $70 \mathrm{mg} / \mathrm{kg}$ [14] and a background concentration range in soil of $10-300 \mathrm{mg} / \mathrm{kg}$. Industrial activities such as mining and smelting [15] and the long-term application of biosolids to agricultural land [16] are the primary sources of anthropogenic $\mathrm{Zn}$ in soils. Pollution of alkaline sandy soils, which are low in organic matter and clay, with $\mathrm{Zn}$ is likely to result in soils with high $\mathrm{Zn}$ phytoavailability and therefore a high risk of plants developing $\mathrm{Zn}$ toxicity at relatively low total $\mathrm{Zn}$ concentrations [17]. Zinc toxicity in plants however has been far less wide spread than cases of $\mathrm{Zn}$ deficiencies [18] [19].

\subsection{Nickel}

Nickel has a crustal abundance range of $37-72 \mathrm{mg} / \mathrm{kg}$ [20] and background concentration of $16.1-30.7 \mathrm{mg} / \mathrm{kg}$ [21]. Smelting, ore refining, mining, combustion of fossil fuels and the long-time application of biosolids to agricultural land 
results in excess $\mathrm{Ni}$ being present in soil [22]. Among various industrial operations manufacturing of alkaline storage batteries have resulted in an increase in the extent of nickel in the environment [23]. Natural sources of Ni include serpentine areas in Venezuela, Australia and New Caledonia [24].

\section{Bioavailability of Heavy Metals in Soils}

The bioavailable fraction of a heavy metal is defined as that proportion of the total pool of heavy metals in a soil that are extractable in a chemical regent and can potentially be absorbed by plants [25]. Heavy metals generally have low solubility and so are mainly in forms that are unavailable for plant uptake [26]. Thus, in natural undisturbed environments, heavy metals are rarely present in high enough bioavailable concentrations to cause significant toxicity to plants.

Heavy metal bioavailability in soil is related to the solubility of contaminant in that soil [15] [27]. However, there is debate as to which fraction of heavy metals in soil corresponds to the bioavailable pool [27]. Bioavailability has been associated with heavy metal ion activity in the soil solution and the exchangeable heavy metal fraction [26] [27]. Nevertheless, there is yet no general consensus among researchers on how to measure bioavailability of heavy metals in soil.

Heavy metal bioavailability, rather than total concentration, is important when accurately assessing the risk associated with soil contamination. Heavy metals that are present in soils occur in several fractions such as the soil solution, exchangeable, organically and colloidally bound, residual and within primary phase of minerals [28]. Soil organisms and plants are not able to access the entire heavy metal pool in the soil. Among these heavy metal fractions, the most available heavy metals and potentially phytotoxic are present in soil solution and absorbed to inorganic soil constituents at ion exchange sites, with the other heavy metal fractions being not/less available for plant uptake [29].

A significant amount is known about the soil factors that affect the bioavailability of heavy metals to plants. Menzies et al concludes on the extractants that most accurately estimate the phytoavailability of metals in soils [30]. Thus, a series of soil properties and processes control bioavailability and mobility of heavy metals in the soils with organic matter, soil $\mathrm{pH}$, redox potential, clay and oxide content [31] [32].

\subsection{Organic Matter}

A fundamental component of soil is the organic matter which has originated from plants and animals and been set down within the earth's structural components [28] [33]. Organic materials can affect the solubility, bioavailability and mobility of heavy metals in soil [14]. Organic matter is involved in the release and retention of heavy metals via cation exchange and adsorption to organic compounds [28]. Studies show that adding organic materials to soil can reduce heavy metal bioavailability and mobility [34]. Generally, stable soluble organic heavy metal complexes are not available for plant uptake and heavy metals, es- 
pecially $\mathrm{Cu}$, may be available in lower amounts as a result of complexing with dissolved organic carbon (DOC) in soil solutions [35] [36].

Humic substances are an important component of soil organic matter that can differ in molecular weight, composition, cation exchange capacity and solubility [28]. Humic substances are often divided into three major fractions: humic acid, fulvic acid and humin based upon solubility in water adjusted to different $\mathrm{pH}$ states [37] [38]. Humic and fulvic acids play an important role in the solubility and binding of heavy metals [39]. Fulvic acid is known to increase the ability of soil solutions to complex heavy metals such as $\mathrm{Cu}$ [40] [41] and $\mathrm{Ni}$ [38]. Nickel ions make strong coordinating complexes with organic matter due to its high electronegativity which is second to $\mathrm{Cu}$ in the soil environment [28]. Studies that show the effects of organic matter on heavy metal solubility and bioavailability revealed that heavy metal availability to plants and mobility in soil increase because of DOC complexation [40]. For example, organic matter affects $\mathrm{Zn}$ solubility by the formation of complexes, although $\mathrm{Zn}$ competes less strongly than $\mathrm{Ca}, \mathrm{Cu}$ and $\mathrm{Ni}$ for binding sites [42].

\subsection{Soil pH}

Soil $\mathrm{pH}$ is a fundamental variable that controls dissolution, precipitation, ion exchange adsorption, redox and other complex reactions within the soil [28]. In the soil solution, $\mathrm{pH}$ is involved in the equilibrium between metal speciation, solubility, adsorption on colloids and sites available for heavy metal exchange and binding [28] [43].

Soil $\mathrm{pH}$ has been found to be a major factor that controls $\mathrm{Cd}$ and $\mathrm{Zn}$ bioavailability [44]. Nickel solubility and toxicity in soils has been positively identified as related to soil $\mathrm{pH}$ and total $\mathrm{Ni}$ content [45]. Generally as the $\mathrm{pH}$ decreases, the solubility and bioavailability of heavy metals increase [46] [47]. It has been found in some studies where $\mathrm{CaCl}_{2}$ extractable $\mathrm{Cu}$ method was used, that there was little relationship between $\mathrm{pH}$ and $\mathrm{Cu}$ availability [41]. The reason for this lack of response to $\mathrm{pH}$ was that $\mathrm{Cu}$ has a strong affinity for organic matter, which dominates $\mathrm{Cu}$ bioavailability in most soils [48] [49]. Thus, dissolved organic matter is often a more important determinant of $\mathrm{Cu}$ bioavailability and solubility than $\mathrm{pH}$ [35] [50].

The soil $\mathrm{pH}$ has a significant effect on the bioavailability of As. Arsenic bioavailability is mostly controlled by adsorption and desorption reactions in soil [28]. The effect of $\mathrm{pH}$ on As adsorption reactions is relatively well understood with acid and alkaline soils having less As adsorption to soil colloids and thus greater As solubility than more neutral soils [51]. With As adsorption the variable $\mathrm{pH}$-dependent charges develop on the soil particle surfaces [52] and influence As desorption over extended periods of time [53].

\subsection{Redox Conditions}

The reduction and oxidation conditions together are referred to as redox condi- 
tions. Redox reactions are simultaneous processes involving electron transfer from a reductant (electron donor) to an oxidant (electron acceptor). Redox conditions in a soil have strong effects on the solubility and speciation of heavy metals in solution [54]. However, redox conditions are not uniform in soils as microbial processes, oxygen concentration, organic matter and $\mathrm{pH}$ influence redox conditions. In particular, redox conditions are known to have significant impacts on $\mathrm{Mn}, \mathrm{Fe}, \mathrm{Cr}, \mathrm{Sb}$ and As speciation as these elements change their redox state depending on the environmental conditions [55] [56]. Many of these elements are more toxic and mobile in their most reduced form e.g. As(III) and $\mathrm{Mn}$ (II) while others are more toxic in their oxidised form e.g. $\mathrm{Cr}(\mathrm{VI})$ [57]. Iron and $\mathrm{Mn}$ are the most common oxides in soils and they become increasingly soluble under reducing conditions. Zinc, $\mathrm{Ni}, \mathrm{Cd}$ and $\mathrm{Cu}$ however are mostly present in the divalent form in soils; as the monovalent forms are greatly unstable and so these metals are not significantly reduced under low redox conditions [58]. Hence, redox conditions are considered to play a smaller role in the solubility and bioavailability of $\mathrm{Zn}, \mathrm{Ni}, \mathrm{Cd}$ and $\mathrm{Cu}$ compared to heavy metals with multiple redox states such as As, $\mathrm{Mn}$ and $\mathrm{Cr}$ [59].

\subsection{Clays and Oxides}

Clays and oxides are accepted as an important mechanism for controlling the solubility of trace metals [42]. Clays and oxides control metal availability by specific adsorption to hydroxyl groups [60], non-specific adsorption to a large number of available binding sites [61], co-precipitation [62] and precipitation [62]. The clay fraction is typically the most influential for cation adsorption reactions, due to the high concentrations of clays in many soils, high surface area and hydroxyl groups present on clay surfaces [28]. Adsorption in soil commonly takes place on the surfaces of clays and oxides. Increasing clays and oxides in soil therefore supplies more sites for adsorption of heavy metals and so reduces the bioavailability of heavy metals [63] [64].

\section{Rhizosphere Processes}

The rhizosphere is the volume of soil that is affected by the presence of roots from growing plants and generally extends out $1-2 \mathrm{~mm}$ from the surface of roots [65]. The rhizosphere has physical, biological and chemical properties that are different to the bulk soil. Due to the microenvironment that the plant root creates, the rhizosphere has a range of different characteristics to the bulk soil for example larger microbial biomass, altered $\mathrm{pH}$, higher dissolved organic carbon from root exudates [66] [67]. Much of the research on the rhizosphere has focused on the nutrition of plants and macronutrients including N, P and C cycling [65] [68]. However, there has also been significant recent rhizosphere research on heavy metals and pollution [69].

Compared to the bulk soil, the rhizosphere is relatively rich in nutrients due to the loss of up to $40 \%$ of plant photosynthates from roots into the surrounding 
soil medium [70]. The importance of rhizosphere microbial populations for maintaining root health, nutrient uptake and tolerating environmental stress is now recognized [71] [72]. The rhizosphere has many characteristics.

In the rhizosphere, plant roots release a broad range of organic compounds such as phytosiderophores, which are mostly non-protein amino acids [73] [74]. Siderophores are mainly synthesized by some microorganisms to solubilize iron under iron deficient conditions [75] [76] also to solubilize other metals ( $\mathrm{Zn}, \mathrm{Cu}$, Cd) [77] [78] [79]. By a specific receptor, the bacteria incorporate the iron siderophore complex [80]. Phytosiderophores released into the soil augment the ability of plants to develop under Fe limiting conditions [73].

Phytohormones are synthesized by both plants and microorganisms in the rhizosphere and result in larger biomass of roots in plants [81]. Phytohormones cover a wide range of chemicals including, auxin, cytokinin, indole-acetic acid, and gibberellin. Among them, auxins are the most common phytohormones that are known to be involved in the stimulation of roots and enhancement of plant growth [82].

\subsection{Rhizosphere pH Changes}

The $\mathrm{pH}$ of the rhizosphere can vary from the bulk soil by up to 2.5 units depending upon plant species and the buffering capacity of the soil [47]. The $\mathrm{pH}$ of the rhizosphere is different to the bulk soil due to the excretion of hydrogen, bicarbonate salts and organic acids by plant roots to balance the internal charge difference in plants from cation and anion uptake by roots and due to $\mathrm{CO}_{2}$ production from microbial activity [68].

\subsection{Role of Rhizobia and Other Microbes}

Rhizobia are bacteria that form symbiotic associations with legumes and are responsible for the fixation of $\mathrm{N}$ from the atmosphere into forms accessible by plant roots e.g. $\mathrm{NH}_{4}^{+}$[33]. Consequently, legumes absorb more cations than anions and, thus, acidify the surrounding rhizosphere [65]. Nitrogen assimilation by rhizobia results in changes of $\mathrm{pH}$ and increases heavy metal solubility and bioavailability where the symbionts exist [83] [84].

Research was carried out in the rhizosphere of $\mathrm{Ni}$ accumulating plants and plants grown on serpentine soils [85] [86] [87]. The findings were that the rhizosphere bacteria increased plant availability of $\mathrm{Ni}$ by increasing $\mathrm{Ni}$ accumulation via the production of siderophores. The siderophores induced the dissolution of minerals carrying $\mathrm{Ni}$ and thus promoted shoot and root biomass indirectly [87] [88].

Among other microbes in the rhizosphere, mycorrhiza is mutualistic associations between certain soil fungi and the roots of most plant species [89]. Research has found that mycorrhiza assist in nutrient uptake at lower concentrations of metals [90]. Also mycorrhiza is able to reduce metal uptake and in some cases increase plant metal tolerance under conditions of metal contamination [91]. For instance, mycorrhizal Trifolium pratense (red clover) plants grown in 
acid soils with high Mn bioavailability had less $\mathrm{Mn}$ in the roots and the shoots than non-mycorrhizal plants [92]. Also mycorrhizae are able to make plants more tolerant of metals when grown in soils containing high heavy metals concentrations (such as $\mathrm{Zn}, \mathrm{Cu}, \mathrm{Mn}, \mathrm{Ni}, \mathrm{Cr}$ ) [93] [94] [95]. Possible mechanisms by which mycorrhizae deal with excess metals include the immobilisation of metals in the fungal hyphae or in root tissue [96].

\section{Heavy Metal Uptake and Transport}

Heavy metals (such as $\mathrm{Fe}, \mathrm{Cu}, \mathrm{Mn}, \mathrm{Zn}$ and $\mathrm{Ni}$ ) are absorbed passively by plant roots via ion channels [97]. The mechanism for uptake is largely defined by the electrochemical gradients that apply to the transport of a specific nutrient [76] [98].

A number of selective transport pathways for heavy metals into plants are now being discovered. For instance, iron bound to phytosiderophores can be transported by Yellow stripel (YS1) across the plasma membrane [99]. Yellow stripe1 gene synthesizes Fe(III)-Phytosiderophore (Fe-III-PS) transporter in maize (Zea mays). Also YS1-like (YSL) family of transporters can mobilize $\mathrm{Zn}$ and $\mathrm{Cu}$ from plant leaves and seeds [100].

Non-selective channels transport $\mathrm{Ca}^{2+}$ across the root membrane, and it is understood that the uptake of other metals at normal soil solution concentrations occur via this pathway [101]. Competition between cations at the surface of the root shows that non-selective channels facilitate the absorption of essential and non-essential metals [76]. As a result, under conditions of elevated heavy metals, competition for the transport sites leads to favouring the absorption of heavy metals over macronutrients, thus inducing or exacerbating deficiencies of nutrient cations [102].

Plants that have Fe deficiency are sometimes found to have higher $\mathrm{Zn}$ and $\mathrm{Mn}$ concentrations as well [103]. In Arabidopsis, root membrane protein IRT1, a general cation transporter, enhances $\mathrm{Zn}$ and $\mathrm{Mn}$ uptake [104]. A number of transporters are responsible for Fe uptake from soil. This involves transporting from the roots to shoots, transporting to generative parts of plant, xylem unloading, mobilization when seed germination occurs and loading-unloading of Fe from vacuoles. The Fe transporters ZmYS1 and OsYSL15 are able to move additional metals other than $\mathrm{Fe}$ such as $\mathrm{Cu}, \mathrm{Zn}$ and $\mathrm{Ni}$ [103].

There are two strategies that plants use for Fe uptake: strategy I and strategy II (Figure 1). Strategy I plants utilize acidification \& reduction reactions to improve Fe solubility and most of these plants belong to the non-grasses. Secreting protons into the rhizosphere lowers the soil $\mathrm{pH}$, and thus, increases Fe solubility. The strategy I mechanism also effects co-suspension of As from Fe oxides or hydroxides. This makes As more soluble and available to plants [105]. Strategy II plants excrete phytosiderophores (PS) which solubilise and bind soil Fe [106]. Strategy II, is utilised by grasses to obtain Fe from soil [103]. Strategy II plants utilizes a chelation mechanism that is utilised by several bacteria and fungi [103]. 
An example of a phytosiderophore is mugineic acid which is secreted by Fe deficient graminaceous plants [107]. In addition to Fe, phytosiderophores have been shown to mobilize and increase uptake of $\mathrm{Zn}$ and $\mathrm{Cd}$ in the rhizosphere of graminaceous plants [9]. This strategy takes place to adapt to alkaline soils wherever rhizosphere acidification becomes hard to happen. The phytosiderophores are strong Fe chelators. These are amalgamated by the plant and secreted into the rhizosphere and there they bind with Fe [103].

\section{Heavy Metal Toxicity in Plants}

The most common evidence of heavy metal toxicity is a decrease in plant growth as metal toxicity increases. However, as various heavy metals have diverse sites of action within plant, the visual toxic response differs among heavy metals and plant species. From Table 1 it can be seen that the critical tissue concentrations for toxicity vary considerably across metal, species, and the plant tissue being measured.

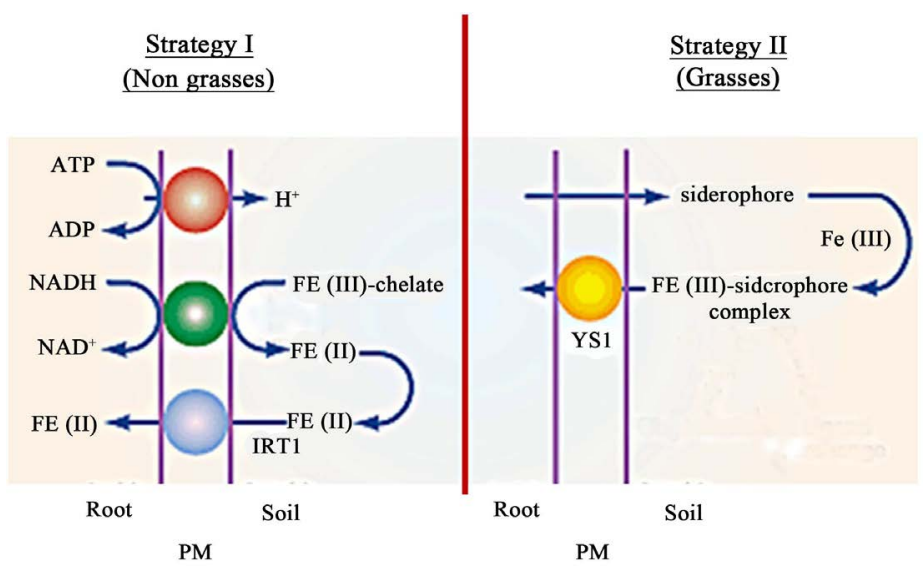

Figure 1. Iron uptake systems of plant roots. Grass and non-grass species acquire iron from the soil through the plasma membrane (PM) of their root by two different strategies (Strategy I and Strategy II, respectively). Strategy I plants reduce Fe(III) to Fe(II), which is then transported across the plasma membrane by the Iron-regulated transporter 1 (IRT1). Strategy II plants release Fe(III) chelating siderophores and then transport Fe(III)-siderophore complexes across the plasma membrane using Yellow stripe 1 (YS1) transporter (partially adapted from [108]).

Table 1. Critical concentrations for for As, Zn, Ni toxicity in soybean and sunflower.

\begin{tabular}{ccccc}
\hline Heavy Metal & Species & Plant part & $\begin{array}{c}\text { Critical toxicity } \\
\left(\mathrm{mg} \cdot \mathrm{kg}^{-1}\right)\end{array}$ & Reference \\
\hline \multirow{2}{*}{ As } & Glycine max (soybean) & Shoot & 299 & {$[109]$} \\
& Helianthus annus (sunflower) & Shoot & 100 & {$[110]$} \\
\multirow{2}{*}{$\mathrm{Zn}$} & Glycine max (soybean) & Leaves & 229 & {$[111]$} \\
& Helianthus annus (sunflower) & Leaves & 190 & {$[112]$} \\
\multirow{2}{*}{$\mathrm{Ni}$} & Glycine max (soybean) & Shoot & 52 & {$[113]$} \\
& Helianthus annus (sunflower) & Leaves & 40 & {$[114]$} \\
\hline
\end{tabular}




\subsection{Arsenic Toxicity}

Arsenic is not essential for plants and appears not to be involved in specific metabolic reactions when supplied at low concentrations [115] [116]. Naturally, As may be present in four oxidation states $-3,0,+3$ and +5 [117]. The major forms of As in the soils are arsenate $(\mathrm{As}(\mathrm{V}))$ and arsenite $(\mathrm{As}(\mathrm{III}))$ [9] with the latter having greater toxicity to most species including plants [118]. The symptoms of As toxicity in plants frequently include poor seed germination and reductions in root growth [119]. These effects may relate to rapid disruption of plasma membrane structure, including fluidisation [120]. At higher concentrations As has been reported to interfere with metabolic processes and sometimes lead to plant death [121]. Where plants survive high As exposure, they may show reduced growth, nutrient deficiencies and chlorosis, resulting from reduced chlorophyll biosynthesis [122] [123], as well as reduced photosynthetic oxygen evolution [124]. Critical concentrations of As in shoot tissue range from approximately 21 to $325 \mu \mathrm{g} / \mathrm{g}$ depending on the species and cultivar [125].

\subsection{Zinc Toxicity}

Symptoms of $\mathrm{Zn}$ toxicity include a general chlorosis of younger leaves where $\mathrm{Zn}$ is present in toxic concentrations in the soils [126] and an overall decrease in leaf size compared to the plants which are unaffected [19]. Chlorosis is the first typical symptom of Zn toxicity [126]. Under further exposure to toxic Zn levels plant symptoms develop into reddened leaves and in severe cases $\mathrm{Zn}$ toxicity can lead to necrosis of the tip of the leaf [73]. Reduction in the growth of main, lateral roots and yellowing of the root is how $\mathrm{Zn}$ toxicity is manifested in roots [19]. Critical toxicity concentrations of $\mathrm{Zn}$ in crop leaves are between $100 \mu \mathrm{g} / \mathrm{g}$ to $>300 \mu \mathrm{g} / \mathrm{g}$ depending on the species [73].

\subsection{Nickel Toxicity}

Moderate concentrations of $\mathrm{Ni}$ can severely limit the growth of plants such as Indian mustard (Brassica juncea) and canola (Brassica napus) [127]. Critical toxicity levels of $\mathrm{Ni}$ are in range of $10 \mu \mathrm{g} / \mathrm{g}$ to $>50 \mu \mathrm{g} / \mathrm{g}$ in crops of moderately tolerant species [73]. In soil, excess $\mathrm{Ni}$ affects root growth with severe inhibition in species that are sensitive to $\mathrm{Ni}$ at concentrations $<5 \mu \mathrm{M}$ in solution culture [73]. The most frequent effect of $\mathrm{Ni}$ toxicity is foliar chlorosis and in some cases decreased growth of root [128] [129].

\section{Concluding Remarks}

Metal contamination issues in plants and soils are becoming progressively shared throughout the world. Metal toxicities are often accompanying with a range of symptoms and an overall decline in plant growth [130] [131] [132]. Contextual knowledge of available different strategies and possible risks of heavy metals is required for the selection of appropriate remedial options. The growth promoting properties of rhizobia to an array of heavy metals for the remediation 
and stabilisation of contaminated land is an area of research that requires to be further explored.

\section{Conflicts of Interest}

The authors declare no conflicts of interest regarding the publication of this paper.

\section{References}

[1] Park, J.H., et al. (2011) Role of Organic Amendments on Enhanced Bioremediation of Heavy Metal(Loid) Contaminated Soils. Journal of Hazardous Materials, 185, 549-574. https://doi.org/10.1016/j.jhazmat.2010.09.082

[2] DEFRA (2002) Contaminated Land Assessment Reports (CLR Reports). Department for Environment, Food and Rural Affairs and the Environment Agency, London.

[3] USEPA (2001) Integrated Risk Information System (IRIS) Risk Information for Lead and Compounds (Inorganic). United States Environmental Protection Agency, Washington DC.

[4] Vodyanitskii, Y.N. (2013) Contamination of Soils with Heavy Metals and Metalloids and Its Ecological Hazard (Analytic Review). Eurasian Soil Science, 46, 793-801. https://doi.org/10.1134/S1064229313050153

[5] WHO Safety Evaluation of Certain Food Additives and Contaminants. Fifty-Third Meeting of the Joint FAO/ WHO Expert Committee on Food Additives, Food Additives Series No. 8302000, Geneva.

[6] El-Nahry, A.H. and Doluschitz, R. (2010) Climate Change and Its Impacts on the Coastal Zone of the Nile Delta, Egypt. Environmental Earth Sciences, 59, 1497-1506. https://doi.org/10.1007/s12665-009-0135-0

[7] Dhillon, K.S. and Dhillon, S.K. (1991) Accumulation of Selenium in Sugarcane (Sachharum officinarum Linn) in Seleniferous Areas of Punjab, India. Environmental Geochemistry and Health, 13, 165-170.

https://doi.org/10.1007/BF01758556

[8] Testiati, E., et al. (2013) Trace Metal and Metalloid Contamination Levels in Soils and in Two Native Plant Species of a Former Industrial Site: Evaluation of the Phytostabilization Potential. Journal of Hazardous Materials, 248, 131-141.

https://doi.org/10.1016/j.jhazmat.2012.12.039

[9] Shenker, M., Fan, T.W.M. and Crowley, D.E. (2001) Phytosiderophores Influence on Cadmium Mobilization and Uptake by Wheat and Barley Plants. Journal of Environmental Quality, 30, 2091-2098. https://doi.org/10.2134/jeq2001.2091

[10] Schallenberg, M., Goff, J. and Harper, M.A. (2012) Gradual, Catastrophic and Human Induced Environmental Changes from a Coastal Lake, Southern New Zealand. Sedimentary Geology, 273, 48-57. https://doi.org/10.1016/j.sedgeo.2012.06.010

[11] Rahman, M.M., et al. (2006) Arsenic Contamination Incidents around the World. In: Managing Arsenic in the Environment: From Soil to Human Health, CSIRO Publishing, Clayton, 3-30

[12] Huq, S.M.I. and Naidu, R. (2005) Arsenic in Groundwater and Contamination of the Food Chain: Bangladesh Scenario. In: Natural Arsenic in Groundwater. Occurrence, Remediation and Management, 95-101.

[13] McLaren, R.G., et al. (1998) Fractionation and Distribution of Arsenic in Soils Con- 
taminated by Cattle Dip. Journal of Environmental Quality, 27, 348-354. https://doi.org/10.2134/jeq1998.00472425002700020015x

[14] Yadav, B.K. and Hassanizadeh, S.M. (2011) An Overview of Biodegradation of LNAPLs in Coastal (Semi)-Arid Environment. Water Air and Soil Pollution, 220, 225-239. https://doi.org/10.1007/s11270-011-0749-1

[15] Degryse, F., Smolders, E. and Parker, D.R. (2009) Partitioning of Metals (Cd, Co, $\mathrm{Cu}, \mathrm{Ni}, \mathrm{Pb}, \mathrm{Zn})$ in Soils: Concepts, Methodologies, Prediction and Applications-A Review. European Journal of Soil Science, 60, 590-612. https://doi.org/10.1111/j.1365-2389.2009.01142.x

[16] Kim, B., et al. (2007) The Long-Term Effect of Sludge Application on Cu, Zn, and Mo Behavior in Soils and Accumulation in Soybean Seeds. Plant and Soil, 299, 227-236. https://doi.org/10.1007/s11104-007-9377-3

[17] Rattan, R.K. and Shukla, L.M. (1984) Critical Limits of Deficiency and Toxicity of Zinc in Paddy in a Typic Ustipsamment. Communications in Soil Science and Plant Analysis, 15, 1041-1050. https://doi.org/10.1080/00103628409367541

[18] Alloway, B.J. (2009) Soil Factors Associated with Zinc Deficiency in Crops and Humans. Environmental Geochemistry and Health, 31, 537-548. https://doi.org/10.1007/s10653-009-9255-4

[19] Broadley, M.R., et al. (2007) Zinc in Plants. New Phytologist, 173, 677-702. https://doi.org/10.1111/j.1469-8137.2007.01996.x

[20] Nriagu, J.O., Wong, H.K.T. and Coker, R.D. (1982) Deposition and Chemistry of Pollutant Metals in Lakes around the Smelters at Sudbury. Ontario Environmental Science \& Technology, 16, 551-560. https://doi.org/10.1021/es00103a004

[21] Gil, C., Boluda, R. and Ramos, J. (2004) Determination and Evaluation of Cadmium, Lead and Nickel in Greenhouse Soils of Almeria (Spain). Chemosphere, 55, 1027-1034. https://doi.org/10.1016/j.chemosphere.2004.01.013

[22] Tye, A.M., et al. (2004) Speciation and Solubility of $\mathrm{Cu}, \mathrm{Ni}$ and $\mathrm{Pb}$ in Contaminated Soils. European Journal of Soil Science, 55, 579-590. https://doi.org/10.1111/j.1365-2389.2004.00627.x

[23] Mcllveen, W.D. and Negusanti, J.J. (1994) Nickel in Terrestrial Environment. Science of the Total Environment, 148, 109-138. https://doi.org/10.1016/0048-9697(94)90390-5

[24] Bonifacio, E., Falsone, G. and Piazza, S. (2010) Linking Ni and Cr Concentrations to Soil Mineralogy: Does It Help to Assess Metal Contamination When the Natural Background Is High? Journal of Soils and Sediments, 10, 1475-1486. https://doi.org/10.1007/s11368-010-0244-0

[25] Fairbrother, A., et al. (2007) Framework for Metals Risk Assessment. Ecotoxicology and Environmental Safety, 68, 145-227. https://doi.org/10.1016/j.ecoenv.2007.03.015

[26] Violante, A., et al. (2010) Mobility and Bioavailability of Heavy Metals and Metalloids in Soil Environments. Journal of Soil Science and Plant Nutrition, 10, 268-292. https://doi.org/10.4067/S0718-95162010000100005

[27] Hooda, P.S. (2007) Speciation and Bioavailability of Metal Contaminants in Soils: Concepts, Approaches and Challenges. Progress in Environmental Science and Technology, 1, 1165-1168.

[28] McBride, M. (1994) Environmental Chemistry of Soils. Environmental Chemistry of Soils, 7, 406.

[29] Peijnenburg, W. and Jager, T. (2003) Monitoring Approaches to Assess Bioaccessi- 
bility and Bioavailability of Metals: Matrix Issues. Ecotoxicology and Environmental Safety, 56, 63-77. https://doi.org/10.1016/S0147-6513(03)00051-4

[30] Menzies, N.W., Donn, M.J. and Kopittke, P.M. (2007) Evaluation of Extractants for Estimation of the Phytoavailable Trace Metals in Soils. Environmental Pollution, 145, 121-130. https://doi.org/10.1016/j.envpol.2006.03.021

[31] Chojnacka, K., et al. (2005) Bioavailability of Heavy Metals from Polluted Soils to Plants. Science of the Total Environment, 337, 175-182. https://doi.org/10.1016/j.scitotenv.2004.06.009

[32] Lair, G.J., Gerzabek, M.H. and Haberhauer, G. (2007) Retention of Copper, Cadmium and Zinc in Soil and Its Textural Fractions Influenced by Long-Term Field Management. European Journal of Soil Science, 58, 1145-1154. https://doi.org/10.1111/j.1365-2389.2007.00905.x

[33] Sessitsch, A., et al. (2002) Advances in Rhizobium Research. Critical Reviews in Plant Sciences, 21, 323-378. https://doi.org/10.1080/0735-260291044278

[34] Hernandez-Soriano, M.C. and Jimenez-Lopez, J.C. (2012) Effects of Soil Water Content and Organic Matter Addition on the Speciation and Bioavailability of Heavy Metals. Science of the Total Environment, 423, 55-61.

https://doi.org/10.1016/j.scitotenv.2012.02.033

[35] Amery, F., et al. (2008) The UV-Absorbance of Dissolved Organic Matter Predicts the Fivefold Variation in Its Affinity for Mobilizing $\mathrm{Cu}$ in an Agricultural Soil Horizon. European Journal of Soil Science, 59, 1087-1095. https://doi.org/10.1111/j.1365-2389.2008.01078.x

[36] Kalis, E.J.J., et al. (2006) Effects of Humic Acid and Competing Cations on Metal Uptake by Lolium perenne. Environmental Toxicology and Chemistry, 25, 702-711. https://doi.org/10.1897/04-576R.1

[37] Senesi, N., et al. (1991) Characterization, Differentiation and Classification of Humic Substances by Fluorescence Spectroscopy. Soil Science, 152, 259-271. https://doi.org/10.1097/00010694-199110000-00004

[38] Doig, L.E. and Liber, K. (2007) Nickel Speciation in the Presence of Different Sources and Fractions of Dissolved Organic Matter. Ecotoxicology and Environmental Safety, 66, 169-177. https://doi.org/10.1016/j.ecoenv.2005.12.011

[39] Tipping, E. (2005) Modelling A1 Competition for Heavy Metal Binding by Dissolved Organic Matter in Soil and Surface Waters of Acid and Neutral pH. Geoderma, 127, 293-304. https://doi.org/10.1016/j.geoderma.2004.12.003

[40] Ashworth, D.J. and Alloway, B.J. (2007) Complexation of Copper by Sewage Sludge-Derived Dissolved Organic Matter: Effects on Soil Sorption Behaviour and Plant Uptake. Water Air and Soil Pollution, 182, 187-196.

https://doi.org/10.1007/s11270-006-9331-7

[41] Sauve, S., et al. (1997) Copper Solubility and Speciation of in Situ Contaminated Soils: Effects of Copper Level, pH and Organic Matter. Water Air and Soil Pollution, 100, 133-149. https://doi.org/10.1023/A:1018312109677

[42] McBride, M., Sauve, S. and Hendershot, W. (1997) Solubility Control of Cu, Zn, Cd and $\mathrm{Pb}$ in Contaminated Soils. European Journal of Soil Science, 48, 337-346. https://doi.org/10.1111/j.1365-2389.1997.tb00554.x

[43] Sauve, S. (2001) Speciation of Metals in Soils. In: Allen, H.E., Ed., Bioavailability of Metals in Terrestrial Ecosystems. Importance of Partitioning for Bioavailability to Invertebrates, Microbes, and Plants, SETAC Press, Pensacola, 7-38.

[44] Antonladis, V., Robinson, J.S. and Alloway, B.J. (2008) Effects of Short-Term pH 
Fluctuations on Cadmium, Nickel, Lead, and Zinc Availability to Ryegrass in a Sewage Sludge-Amended Field. Chemosphere, 71, 759-764.

https://doi.org/10.1016/j.chemosphere.2007.10.015

[45] Rooney, C.P., Zhao, F.J. and McGrath, S.P. (2007) Phytotoxicity of Nickel in a Range of European Soils: Influence of Soil Properties, Ni Solubility and Speciation. Environmental Pollution, 145, 596-605. https://doi.org/10.1016/j.envpol.2006.04.008

[46] Schachtman, D.P., et al. (1997) Molecular and Functional Characterization of a Novel Low-Affinity Cation Transporter (LCT1) in Higher Plants. Proceedings of the National Academy of Sciences of the United States of America, 94, 11079-11084. https://doi.org/10.1073/pnas.94.20.11079

[47] Fox, T.C. and Guerinot, M.L. (1998) Molecular Biology of Cation Transport in Plants. Annual Review of Plant Physiology and Plant Molecular Biology, 49, 669-696. https://doi.org/10.1146/annurev.arplant.49.1.669

[48] Burton, E.D., et al. (2005) Copper Behaviour in a Podosol. 1. pH-Dependent Sorption-Desorption, Sorption Isotherm Analysis, and Aqueous Speciation Modelling. Australian Journal of Soil Research, 43, 491-501. https://doi.org/10.1071/SR04117

[49] Burton, E.D., et al. (2005) Copper Behaviour in a Podosol. 2. Sorption Reversibility, Geochemical Partitioning, and Column Leaching. Australian Journal of Soil Research, 43, 503-513. https://doi.org/10.1071/SR04118

[50] Amery, F., et al. (2007) The Copper-Mobilizing-Potential of Dissolved Organic Matter in Soils Varies 10-Fold Depending on Soil Incubation and Extraction Procedures. Environmental Science \& Technology, 41, 2277-2281. https://doi.org/10.1021/es062166r

[51] Zhang, S.Z., et al. (2005) Effects of Low Molecular Weight Organic Anions on the Release of Arsenite and Arsenate from a Contaminated Soil. Water Air and Soil Pollution, 167, 111-122. https://doi.org/10.1007/s11270-005-8219-2

[52] Goh, K.H. and Lim, T.T. (2004) Geochemistry of Inorganic Arsenic and Selenium in a Tropical Soil: Effect of Reaction Time, $\mathrm{pH}$, and Competitive Anions on Arsenic and Selenium Adsorption. Chemosphere, 55, 849-859.

https://doi.org/10.1016/j.chemosphere.2003.11.041

[53] Quaghebeur, M., et al. (2005) Desorption Kinetics of Arsenate from Kaolinite as Influenced by $\mathrm{pH}$. Journal of Environmental Quality, 34, 479-486.

[54] Cao, X.D., et al. (2001) Effects of Redox Potential and pH Value on the Release of Rare Earth Elements from Soil. Chemosphere, 44, 655-661. https://doi.org/10.1016/S0045-6535(00)00492-6

[55] Borch, T., et al. (2010) Biogeochemical Redox Processes and Their Impact on Contaminant Dynamics. Environmental Science \& Technology, 44, 15-23. https://doi.org/10.1021/es9026248

[56] Hopkinson, B.M. and Barbeau, K.A. (2007) Organic and Redox Speciation of Iron in the Eastern Tropical North Pacific Suboxic Zone. Marine Chemistry, 106, 2-17. https://doi.org/10.1016/j.marchem.2006.02.008

[57] Oorts, K., et al. (2008) Solubility and Toxicity of Antimony Trioxide $\left(\mathrm{Sb}_{2} \mathrm{O}_{3}\right)$ in Soil. Environmental Science \& Technology, 42, 4378-4383. https://doi.org/10.1021/es703061t

[58] Whitehead, D.C. (2000) Nutrient Elements in Soils. Nutrient Elements in Grasslands: Soil-Plant-Animal Relationships. CABI Publishing, Wallingford, 15-40. https://doi.org/10.1079/9780851994376.0015 
[59] Moraghan, J.T. and Macagni Jnr, H.J. (1991) Environmental Factors Affecting Micronutrient Deficiencies and Toxicities. In: Micronutrients in Agriculture, 2nd Edition, Soil Science Society of America, Madison, 371-425.

[60] Pampura, T.B., et al. (1993) Experimental-Study of the Buffer Capacity of Chernozem Contaminated with Copper and Zinc. Eurasian Soil Science, 25, 27-38.

[61] Basta, N.T. and Tabatabai, M.A. (1992) Effect of Cropping Systems on Adsorption of Metals by Soils. 2. Effect of pH. Soil Science, 153, 195-204. https://doi.org/10.1097/00010694-199203000-00004

[62] Martinez, C.E. and McBride, M.B. (1998) Solubility of $\mathrm{Cd}^{2+}, \mathrm{Cu}^{2+}, \mathrm{Pb}^{2+}$, and $\mathrm{Zn}^{2+}$ in Aged Coprecipitates with Amorphous Iron Hydroxides. Environmental Science \& Technology, 32, 743-748. https://doi.org/10.1021/es970262+

[63] Barrow, N.J. (1993) Mechanisms of Reaction of Zinc with Soil and Soil Components. Zinc in Soils and Plants, 55, 15-31. https://doi.org/10.1007/978-94-011-0878-2_2

[64] Qiao, L. and Ho, G. (1996) The Effect of Clay Amendment on Speciation of Heavy Metals in Sewage Sludge. Water Science and Technology, 34, 413-420. https://doi.org/10.2166/wst.1996.0649

[65] Gregory, P.J. (2006) Roots, Rhizosphere and Soil: The Route to a Better Understanding of Soil Science? European Journal of Soil Science, 57, 2-12. https://doi.org/10.1111/j.1365-2389.2005.00778.x

[66] Jones, D.L. (1998) Organic Acids in the Rhizosphere-A Critical Review. Plant and Soil, 205, 25-44. https://doi.org/10.1023/A:1004356007312

[67] Jones, D.L., Nguyen, C. and Finlay, R.D. (2009) Carbon Flow in the Rhizosphere: Carbon Trading at the Soil-Root Interface. Plant and Soil, 321, 5-33. https://doi.org/10.1007/s11104-009-9925-0

[68] Jones, D.L., Hodge, A. and Kuzyakov, Y. (2004) Plant and Mycorrhizal Regulation of Rhizodeposition. New Phytologist, 163, 459-480. https://doi.org/10.1111/j.1469-8137.2004.01130.x

[69] Khan, M.S., et al. (2009) Role of Plant Growth Promoting Rhizobacteria in the Remediation of Metal Contaminated Soils. Environmental Chemistry Letters, 7, 1-19. https://doi.org/10.1007/s10311-008-0155-0

[70] Lynch, J.M. and Whipps, J.M. (1991) Substrate Flow in the Rhizosphere, in the Rhizosphere and Plant Growth. Kluwer, Dordrecht, 15-24. https://doi.org/10.1007/978-94-011-3336-4_2

[71] Bowen, G.D. and Rovira, A.D. (1999) The Rhizosphere and Its Management to Improve Plant Growth. Advances in Agronomy, 66, 1-102. https://doi.org/10.1016/S0065-2113(08)60425-3

[72] Cook, R.J. (2000) Advances in Plant Health Management in the Twentieth Century. Annual Review of Phytopathology, 38, 95-116. https://doi.org/10.1146/annurev.phyto.38.1.95

[73] Marschner, H. (1995) Mineral Nutrition of Higher Plants. 2nd Edition, Academic Press, San Diego, 874-889.

[74] Muller, S., et al. (1993) An Automated-System for Large-Scale Recovery of Germination Stimulants and Other Root Exudates. Weed Science, 41, 138-143.

[75] Haas, D. and Defago, G. (2005) Biological Control of Soil-Borne Pathogens by Fluorescent Pseudomonads. Nature Reviews Microbiology, 3, 307-319. https://doi.org/10.1038/nrmicro1129

[76] Reid, R. and Hayes, J. (2003) Mechanisms and Control of Nutrient Uptake in 
Plants. International Review of Cytology: A Survey of Cell Biology, 229, 73-114. https://doi.org/10.1016/S0074-7696(03)29003-3

[77] Zhang, F.S., Romheld, V. and Marschner, H. (1991) Diurnal Rhythm of Release of Phytosiderophores and Uptake Rate of Zinc in Iron-Deficient Wheat. Soil Science and Plant Nutrition, 37, 671-678. https://doi.org/10.1080/00380768.1991.10416935

[78] Zhang, F.S. (1993) Mobilization of Iron and Manganese by Plant-Borne and Synthetic Metal Chelators. Plant and Soil, 155, 111-114. https://doi.org/10.1007/BF00024996

[79] Zhang, F.S., et al. (2001) Evaluation of Cadmium and Other Metal Losses from Various Municipal Wastes during Incineration Disposal. Environmental Pollution, 115, 253-260. https://doi.org/10.1016/S0269-7491(01)00104-X

[80] Buysens, S., et al. (1996) Involvement of Pyochelin and Pyoverdin in Suppression of Pythium-Induced Damping-Off of Tomato by Pseudomonas aeruginosa 7NSK2. Applied and Environmental Microbiology, 62, 865-871.

[81] Steenhoudt, O. and Vanderleyden, J. (2000) Azospirillum, a Free-Living Nitrogen-Fixing Bacterium Closely Associated with Grasses: Genetic, Biochemical and Ecological Aspects. FEMS Microbiology Reviews, 24, 487-506.

https://doi.org/10.1111/j.1574-6976.2000.tb00552.x

[82] Bloemberg, G.V. and Lugtenberg, B.J.J. (2001) Molecular Basis of Plant Growth Promotion and Biocontrol by Rhizobacteria. Current Opinion in Plant Biology, 4, 343-350. https://doi.org/10.1016/S1369-5266(00)00183-7

[83] Chaudri, A., et al. (2008) Population Size of Indigenous Rhizobium leguminosarum Biovar Trifolii in Long-Term Field Experiments with Sewage Sludge Cake, Metal-Amended Liquid Sludge or Metal Salts: Effects of Zinc, Copper and Cadmium. Soil Biology \& Biochemistry, 40, 1670-1680.

https://doi.org/10.1016/j.soilbio.2008.01.026

[84] Kopittke, P.M., Dart, P.J. and Menzies, N.W. (2007) Toxic Effects of Low Concentrations of $\mathrm{Cu}$ on Nodulation of Cowpea (Vigna unguiculata). Environmental Pollution, 145, 309-315. https://doi.org/10.1016/j.envpol.2006.03.007

[85] Elaziz, R., Angle, J.S. and Chaney, R.L. (1991) Metal Tolerance of Rhizobium meliloti Isolated from Heavy-Metal Contaminated Soils. Soil Biology \& Biochemistry, 23, 795-798. https://doi.org/10.1016/0038-0717(91)90151-9

[86] Idris, R., et al. (2004) Bacterial Communities Associated with Flowering Plants of the Ni Hyperaccumulator Thlaspi goesingense. Applied and Environmental Microbiology, 70, 2667-2677. https://doi.org/10.1128/AEM.70.5.2667-2677.2004

[87] Ma, Y., Rajkumar, M. and Freitas, H. (2009) Isolation and Characterization of Ni Mobilizing PGPB from Serpentine Soils and Their Potential in Promoting Plant Growth and Ni Accumulation by Brassica spp. Chemosphere, 75, 719-725. https://doi.org/10.1016/j.chemosphere.2009.01.056

[88] Wenzel, W.W., et al. (2003) Rhizosphere Characteristics of Indigenously Growing Nickel Hyperaccumulator and Excluder Plants on Serpentine Soil. Environmental Pollution, 123, 131-138. https://doi.org/10.1016/S0269-7491(02)00341-X

[89] Brundrett, M.C., Ashwath, N. and Jasper, D.A. (1996) Mycorrhizas in the Kakadu Region of Tropical Australia. 1. Propagules of Mycorrhizal Fungi and Soil Properties in Natural Habitats. Plant and Soil, 184, 159-171. https://doi.org/10.1007/BF00029285

[90] Arines, J. and Vilarino, A. (1989) Use of Nutrient-Phosphorus Ratios to Evaluate the Effects of Vesicular-Arbuscular Mycorrhiza on Nutrient-Uptake in Unsterilized 
Soils. Biology and Fertility of Soils, 8, 293-297. https://doi.org/10.1007/BF00263157

[91] Weissenhorn, I., et al. (1995) Arbuscular mycorrhizal Contribution to Heavy Metal Uptake by Maize (Zea mays L.) in Pot Culture with Contaminated Soil. Mycorrhiza, 5, 245-251.

[92] Arines, J., Vilarino, A. and Sainz, M. (1989) Effect of Different Inocula of Vesicular-Arbuscular Mycorrhizal Fungi on Manganese Content and Concentration in Red-Clover (Trifolium pratense L.) Plants. New Phytologist, 112, 215-219. https://doi.org/10.1111/j.1469-8137.1989.tb02376.x

[93] Bucking, H. and Heyser, W. (1994) The Effect of Ectomycorrhizal Fungi on Zn Uptake and Distribution in Seedlings of Pinus sylvestris L. Plant and Soil, 167, 203-212. https://doi.org/10.1007/BF00007946

[94] Denny, H.J. and Ridge, I. (1995) Fungal Slime and Its Role in the Mycorrhizal Amelioration of Zinc Toxicity to Higher-Plants. New Phytologist, 130, 251-257. https://doi.org/10.1111/j.1469-8137.1995.tb03046.x

[95] Leyval, C., Turnau, K. and Haselwandter, K. (1997) Effect of Heavy Metal Pollution on Mycorrhizal Colonization and Function: Physiological, Ecological and Applied Aspects. Mycorrhiza, 7, 139-153. https://doi.org/10.1007/s005720050174

[96] Hildebrandt, U., Kaldorf, M. and Bothe, H. (1999) The Zinc Violet and Its Colonization by Arbuscular Mycorrhizal Fungi. Journal of Plant Physiology, 154, 709-717. https://doi.org/10.1016/S0176-1617(99)80249-1

[97] Weis, J.S. and Weis, P. (2004) Metal Uptake, Transport and Release by Wetland Plants: Implications for Phytoremediation and Restoration. Environment International, 30, 685-700. https://doi.org/10.1016/j.envint.2003.11.002

[98] Reid, R.J. (2001) Mechanisms of Micronutrient Uptake in Plants. Australian Journal of Plant Physiology, 28, 659-666.

[99] Roberts, L.A., et al. (2004) Yellow Stripe 1. Expanded Roles for the Maize Iron-Phytosiderophore Transporter. Plant Physiology, 135, 112-120. https://doi.org/10.1104/pp.103.037572

[100] Curie, C., et al. (2009) Metal Movement within the Plant: Contribution of Nicotianamine and Yellow Stripe 1-Like Transporters. Annals of Botany, 103, 1-11. https://doi.org/10.1093/aob/mcn207

[101] Reid, R.J., Dunbar, K.R. and McLaughlin, M.J. (2003) Cadmium Loading into Potato Tubers: The Roles of the Periderm, Xylem and Phloem. Plant Cell and Environment, 26, 201-206. https://doi.org/10.1046/j.1365-3040.2003.00945.x

[102] Palmer, C.M. and Guerinot, M.L. (2009) Facing the Challenges of $\mathrm{Cu}, \mathrm{Fe}$ and $\mathrm{Zn}$ Homeostasis in Plants. Nature Chemical Biology, 5, 333-340. https://doi.org/10.1038/nchembio.166

[103] Conte, S.S. and Walker, E.L. (2011) Transporters Contributing to Iron Trafficking in Plants. Molecular Plant, 4, 464-476. https://doi.org/10.1093/mp/ssr015

[104] Vert, G., et al. (2002) IRT1, an Arabidopsis Transporter Essential for Iron Uptake from the Soil and for Plant Growth. Plant Cell, 14, 1223-1233. https://doi.org/10.1105/tpc.001388

[105] Fitz, W.J. and Wenzel, W.W. (2002) Arsenic Transformations in the Soil-Rhizosphere-Plant System: Fundamentals and Potential Application to Phytoremediation. Journal of Biotechnology, 99, 259-278. https://doi.org/10.1016/S0168-1656(02)00218-3

[106] Von Wiren, N., Khodr, H. and Hider, R.C. (2000) Hydroxylated Phytosiderophore Species Possess an Enhanced Chelate Stability and Affinity for Iron (III). Plant 
Physiology, 124, 1149-1157. https://doi.org/10.1104/pp.124.3.1149

[107] Suzuki, M., et al. (2006) Biosynthesis and Secretion of Mugineic Acid Family Phytosiderophores in Zinc-Deficient Barley. Plant Journal, 48, 85-97. https://doi.org/10.1111/j.1365-313X.2006.02853.x

[108] Guerinot, M.L. (2001) Improving Rice Yields-Ironing out the Details. Nature Biotechnology, 19, 417-418. https://doi.org/10.1038/88067

[109] Cao, H.C., et al. (2009) Potential Ecological Risk of Cadmium, Lead and Arsenic in Agricultural Black Soil in Jilin Province, China. Stochastic Environmental Research and Risk Assessment, 23, 57-64. https://doi.org/10.1007/s00477-007-0195-1

[110] Lyubun, Y.V., Kosterin, P.V., Zakharova, E.A., Shcherbakov, A.A. and Fedorov, E.F. (2002) Arsenic-Contaminated Soils Phytotoxicity Studies with Sunflower and Sorghum. Journal of Soils and Sediments, 2, 143-147. https://doi.org/10.1007/BF02988466

[111] Borkert, C.M., Cox, F.R. and Tucker, M.R. (1998) Zinc and Copper Toxicity in Peanut, Soybean, Rice, and Corn in Soil Mixtures. Communications in Soil Science and Plant Analysis, 29, 2991-3005. https://doi.org/10.1080/00103629809370171

[112] Khurana, N. and Chatterjee, C. (2001) Influence of Variable Zinc on Yield, Oil Content, and Physiology of Sunflower. Communications in Soil Science and Plant Analysis, 32, 3023-3030. https://doi.org/10.1081/CSS-120001104

[113] Kukier, U. and Chaney, R.L. (2004) In Situ Remediation of Nickel Phytotoxicity for Different Plant Species. Journal of Plant Nutrition, 27, 465-495. https://doi.org/10.1081/PLN-120028874

[114] Ahmad, M.S.A., Ashraf, M. and Hussain, M. (2011) Phytotoxic Effects of Nickel on Yield and Concentration of Macro- and Micro-Nutrients in Sunflower (Helianthus annuus L.) Achenes. Journal of Hazardous Materials, 185, 1295-1303. https://doi.org/10.1016/j.jhazmat.2010.10.045

[115] Zhao, F.J., et al. (2009) Arsenic Uptake and Metabolism in Plants. New Phytologist, 181, 777-794. https://doi.org/10.1111/j.1469-8137.2008.02716.x

[116] Abedin, M.J., Feldmann, J. and Meharg, A.A. (2002) Uptake Kinetics of Arsenic Species in Rice Plants. Plant Physiology, 128, 1120-1128. https://doi.org/10.1104/pp.010733

[117] Hughes, M.F., et al. (2011) Arsenic Exposure and Toxicology: A Historical Perspective. Toxicological Sciences, 123, 305-332. https://doi.org/10.1093/toxsci/kfr184

[118] Finnegan, P.M. and Chen, W. (2012) Arsenic Toxicity: The Effects on Plant Metabolism. Frontiers in Physiology, 3, 182-182.

https://doi.org/10.3389/fphys.2012.00182

[119] Garg, N. and Singla, P. (2011) Arsenic Toxicity in Crop Plants: Physiological Effects and Tolerance Mechanisms. Environmental Chemistry Letters, 9, 303-321. https://doi.org/10.1007/s10311-011-0313-7

[120] Smith, S.E., et al. (2010) Arsenic Uptake and Toxicity in Plants: Integrating Mycorrhizal Influences. Plant and Soil, 327, 1-21. https://doi.org/10.1007/s11104-009-0089-8

[121] Tripathi, R.D., et al. (2007) Arsenic Hazards: Strategies for Tolerance and Remediation by Plants. Trends in Biotechnology, 25, 158-165. https://doi.org/10.1016/j.tibtech.2007.02.003

[122] Mascher, R., et al. (2002) Arsenate Toxicity: Effects on Oxidative Stress Response Molecules and Enzymes in Red Clover Plants. Plant Science, 163, 961-969.

https://doi.org/10.1016/S0168-9452(02)00245-5 
[123] Singh, N., et al. (2006) Metabolic Adaptations to Arsenic-Induced Oxidative Stress in Pteris vittata L. and Pteris ensiformis L. Plant Science, 170, 274-282. https://doi.org/10.1016/j.plantsci.2005.08.013

[124] Ullricheberius, C.I., Sanz, A. and Novacky, A.J. (1989) Evaluation of Arsenate-Associated and Vanadate-Associated Changes of Electrical Membrane-Potential and Phosphate Transport in Lemna-gibba-g1. Journal of Experimental Botany, 40, 119-128. https://doi.org/10.1093/jxb/40.1.119

[125] Shaibur, M.R., et al. (2008) Critical Toxicity Level of Arsenic and Elemental Composition of Arsenic-Induced Chlorosis in Hydroponic Sorghum. Water Air and Soil Pollution, 191, 279-292. https://doi.org/10.1007/s11270-008-9624-0

[126] Reichman, S.M., et al. (2001) Seedling Responses of Three Australian Tree Species to Toxic Concentrations of Zinc in Solution Culture. Plant and Soil, 235, 151-158. https://doi.org/10.1023/A:1011903430385

[127] Tank, N. and Saraf, M. (2009) Enhancement of Plant Growth and Decontamination of Nickel-Spiked Soil Using PGPR. Journal of Basic Microbiology, 49, 195-204. https://doi.org/10.1002/jobm.200800090

[128] Himmelbauer, M.L., et al. (2005) Root Morphology of Thlaspi goesingense Halacsy Grown on a Serpentine Soil. Journal of Plant Nutrition and Soil Science, 168, 138-144. https://doi.org/10.1002/jpln.200420434

[129] Molas, J. and Baran, S. (2004) Relationship between the Chemical form of Nickel Applied to the Soil and Its Uptake and Toxicity to Barley Plants (Hordeum vulgare L.). Geoderma, 122, 247-255. https://doi.org/10.1016/j.geoderma.2004.01.011

[130] Rascio, N. and Navari-Izzo, F. (2011) Heavy Metal Hyperaccumulating Plants: How and Why Do They Do It? And What Makes Them So Interesting? Plant Science, 180, 169-181. https://doi.org/10.1016/j.plantsci.2010.08.016

[131] Kalyanaraman, S.B. and Sivagurunathan, P. (1993) Effect of Cadmium, Copper and Zinc on the Growth of Blackgram. Journal of Plant Nutrition, 16, 2029-2042. https://doi.org/10.1080/01904169309364672

[132] Reichman, S.M. (2002) The Responses of Plants to Metal Toxicity: A Review Focusing on Copper, Manganese and Zinc. Australian Minerals and Energy Environment Foundation, Melbourne, 54. 